\title{
LINGUISTIC REPRESENTATION OF EMOTIONS IN JAPANESE AND HUNGARIAN: QUANTITY AND ABSTRACTNESS
}

\author{
Márton SZEMEREY \\ Károli Gáspár University of the Reformed Church in Hungary \\ mszemerey@gmail.com
}

\begin{abstract}
In the present paper, two linguistic aspects of emotion expression are studied in the form they are performed in present day Japanese and Hungarian. After a brief summary on the recent emotional researches connected to Japanese culture and language, the concept of Linguistic Category Model is introduced. The quantitative study presented afterwards investigates emotion expression in terms of amount and abstraction. Translations were used for comparison and the results showed that 1) Japanese tend to use less explicit emotion terms compared to Hungarians and 2) emotion language in Japanese is characterized by the choice of less abstract phrases compared to Hungarian. These findings are discussed in the light of their relevance to former researches of cross-cultural psychology and linguistics.
\end{abstract}

\section{Keywords}

Emotion; Emotion regulation; Linguistic Category Model; Linguistic Abstraction

\section{Izvleček}

Članek razpravlja o dveh lingvističnih vidikih čustvenih izrazov v japonščini in madžarščini. V uvodu avtor predstavi dosedanje raziskave s tega področja, ki zadevajo japonski jezik, in se osredotoči na t.i. Lingvistični kategorični model. V kvantitativni raziskavi spremlja pojavnost in abstrakcijo čustvenih izrazov - za primerjavo med jezikoma so uporabljeni prevodi - in rezultati so pokazali dvoje. Prvič, japonci v primerjavi z madžari uporabljajo manj abstraktne čustvene izraze, in drugič, čustveni jezik je v japonščini opisan z manj abstraktnimi frazami kot $\mathrm{v}$ madžarščini. Ugotovitve so na koncu analizirane v luči dosedanjih raziskav s področij psihologije in lingvistike.

\section{Ključne besede}

Čustva; ureditev čustvenih izrazov; Lingvistični kategorični model; lingvistična abstraktnost 


\section{Introduction}

The way emotions appear in the communicational habits of Japan is a largely investigated field in both linguistics and psychology. A number of studies focus on the lexical and grammatical features characterizing emotion terms in Japanese (Maeda, 1993; Ohso, 2001, Kiyomi, 2006), and the semantic structure of emotion expression is also closely connected to this topic (Romney, Kimball, Rusch, 1997). In cross-cultural psychology, several authors describe a specific range of emotions, more accessible than others to Japanese (Doi, 1981; Morschbach \& Tyler, 1986; Markus \& Kitayama, 1991; Kitayama, Mesquita, Karasawa, 2006). Other studies discuss the Japanese cultural scripts, which guide the order of expressing and understanding emotions (Wierzbicka, 1996), emotion inference (Uchida et al., 2009) and co-occurrence of positive and negative emotions in Japan (Miyamoto, Uchida, Ellsworth, 2010; Uchida \& Kitayama, 2009).

Emotion regulation is another research area, which has been given considerable attention recently. Extensive studies have shown, that emotional display rules in Japan result in a reduced expression of negative emotions compared to U.S. and Canada (Safdar et al., 2009). Among members of other cultures that value hierarchy and emphasize long-term orientation, Japanese have also been reported to get relatively high scores on both reappraisal and suppression, i.e. a frequent application of the tools for emotion regulation was found in Japan (Matsumoto et al., 2008). Furthermore, studies using retrospective memory tests show a tendency to dampen positive emotions in the case of participants from Japan along with those from China and Korea (Miyamoto \& Ma, 2011). These results are in line with the findings of Ekman (1972) about emotional display rules allowing Japanese a reduced expression of disgust when engaging in social interactions.

The above mentioned psychological researches examine and compare the way Japanese and non-Japanese people customarily express emotions during events of everyday communication. To do so, sometimes participants were asked to judge the appropriateness of showing certain emotions in certain situations, or their facial expressions and bodily gestures were analyzed under artificially created conditions, while the question of emotional language use was often left untouched. Considering the difficulties of coding every feature of speech that can have an emotional implication, such as tempo, intonation, accent, tone, etc., the decision to design studies that are less dependent on verbal aspects of the interactions is not at all implausible. However, unlike the above interactions, that have the merits of both verbal and nonverbal communication, any classical genre of written communication renders emotion expression unpronounced and almost exclusively linguistic. ${ }^{1}$ Thus it seems to

\footnotetext{
${ }^{1}$ The sudden spread of emoticons, the pictorial representations of facial emotion expressions, like $=)$ 'smile' has created a new method of displaying feelings. Nevertheless, emoticons appear mostly in online communication, whereas offline writings of any genre still use primarily language as a tool of emotion expression.
} 
be reasonable to ask, whether the tendencies found in a series of basically nonlinguistic researches are also reflected in the emotion expression of written language.

Before exploring that question it may be beneficial to discuss an instrument the linguistic representation of emotions can be examined with.

\section{The Linguistic Category Model}

The Linguistic Category Model (Semin \& Fiedler, 1988, 1991; henceforth: LCM) is a framework of vocabulary analysis that makes it possible to decipher the linguistic representation of an interaction in terms of psychological concreteness and abstractness. Concreteness here refers to form of describing an interaction in a way that provides information more or exclusively about the action and less or not at all about the character of the agent. A concrete statement does not allow the listener to value the personality of the agent as such a description refrains from exceeding beyond the scope of an explanation of the interaction on the physical level ("A gave a rose to B"). A word-choice of that kind makes it unclear what kind of person $\mathrm{A}$ is, and also the speaker's evaluation about the interaction remains obscure (Bigazzi \& Nencini, 2008, p. 100). I.e. in different contexts giving a rose can be a sign of courtesy, affection, congratulation, insult, threat, etc., but without additional information about the situation the listener can know neither the exact meaning of the act nor the psychological features of the agent. It is possible though to explain the same situation including the speaker's interpretation about the scene ("A congratulated B"), or describing it not so much as an action, but as a state, and thus offering information in relation to the somewhat long-lasting inner conditions of the agent ("A likes B"). In LCM such a interpretative formulations are understood as more abstract, as the listener has the opportunity to evaluate both the interaction and the character of the agent. The latter wording is least concrete among these in that it tells the listener less about the interaction and more about the agent. The less information about the situation is needed to obtain knowledge about a described person's characteristics and features, as supposed by the speaker, the more abstract the linguistic forms are considered in LCM. The most conceptual and thus abstract forming of the description would be an overt, general evaluation containing only the agent (Semin, 2004) and requiring no further information to draw an inference about his general attitudes ("A is a kind person").

The LCM divides words describing interactions into the following six categories:

a) Descriptive Action Verb (DAV): Verbs describing an action with a clear beginning and end, containing an invariant physical element. E.g., hit, kick, walk

b) Interpretative Action Verb (IAV): Verbs describing a number of actions with a clear beginning and end, without an invariant physical element, reflecting the speaker's interpretation about the interaction. E.g., help, congratulate, hurt 
c) State Action Verb (SAV): Verbs describing an action but referring more to the emotional state resulting from it. E.g., surprise, frighten, fascinate

d) State Verb (SV): Verbs describing an enduring cognitive or emotional state, without a clear beginning or ending. E.g., love, hate, admire

e) Adjective (ADJ): Adjectives describing characteristics of a person. ${ }^{2}$ E.g., kind, depressed, precise

f) Noun (N): Nouns describing characteristics of a person. E.g., thief, criminal, angel

These categories are further classified into four levels of abstractness. When coding a word in terms of concreteness-abstractness, DAV has score 1, IAV and SAV representing only slight difference in abstraction both have score 2, SV has score 3, whereas $\mathrm{ADJ}$ and $\mathrm{N}$ have score 4 again both being almost equally abstract in a psychological sense. Adverbs are coded and scored as ADJ. ${ }^{3}$ It is notable that despite abstraction here refers to a psychological feature, as it is displayed by linguistic markers, in the LCM terminology it is referred to as linguistic abstraction.

During the last twenty five years, LCM has proven a useful tool to reveal new aspects of several phenomena, such as attribution (Semin \& Fiedler, 1989), stereotype formation (Maass, Salvi, Arcuri, Semin, 1989; Maass, 1999; Tanabe \& Oka, 2001) and person-representation (Maass, Karasawa, Politi, Suga, 2006). Another field of application was the linguistic representation of emotions (Semin, Görts, Nandram, Semin-Goossens, 2002). In their study, Semin et al. examined cultural perspectives of emotion expression and found systematic differences between cultures that value relationships and interdependence (e.g., Turkish and Hindustani-Surinamese people) and those emphasizing more the value of the individual (e.g., Dutch people). While the formers seem to use emotion expressions in the function of relationship-markers, the members of the latter group are likely to use emotions to mark the self and tend to describe emotionally filled events of interaction with more abstract linguistic categories (ADJ, N).

This section has been devoted to the LCM and a brief introduction to a research that contributes directly to the understanding of cross-cultural patterns in emotion expression on the basis of that model. It can be seen, that LCM helps us decode emotion expressions in terms of abstractness. This is a different dimension, compared to the emotion display rules, discussed in the Introduction. On the one hand, rules of emotion regulation give us a hint on the amount of the emotion terms. On the other

\footnotetext{
${ }^{2}$ In e) and f) person refers to any kind of agent in an interaction, including animals, natural phenomena, etc.

${ }^{3}$ In the case of Japanese, much onomatopoeia belong to explicit emotion terms what makes it necessary to include them in the above categorizing and scoring system. However, as in the chosen text no such term appears, that question is not discussed in the present paper.
} 
hand, LCM shows the degree of concreteness of emotion terms used in a language. Thus we arrived to the two topics to be discussed below: abstraction and quantity.

\section{Hypotheses}

(1) Emotion regulation characterizing a culture should have a measurable impact on the linguistic representation of emotions in that culture. In case of Japan less emotion terms should appear in a Japanese text compared to its corresponding version produced in a Western language.

(2) Cultures that emphasize interdependence tend to avoid direct evaluation through highly de-contextualized representation of emotions and rather refer to the present situation, or the present relationship. Thus emotion expression in Japanese should be formulated in less abstract terms compared to those in a Western language.

\section{Method}

Participants. 5 female (Mean age=22 years; Standard Deviation=1,581) and 5 male (Mean age $=24,8$ years; Standard Deviation=4,086) students from universities in Budapest volunteered to participate in this study. All of them were majoring Japanese language and were in the last year before, or the year after graduation (Mean time of Japanese language learning=31,1 months; Standard Deviation=9,338). All of them are native Hungarians without considerable experience in professional translation.

Procedure and materials. In order to produce Japanese and Hungarian texts corresponding in terms of topic, style and length the study was based on translation. A part (330 words) of the popular novel Kitchin (Yoshimoto, 1991) was chosen. As the main interest of the study lies in the expression of emotions, the part was selected with regard to the emotions appearing in it. A monologue of an emotion event occupies more than half of the text and the narrator reports her feelings at the end of the section as well. A literal translation of the text was made to Hungarian, strictly preserving part of speech, number and case of every word.

To identify emotion expressions in this translation we used the interface of the program NooJ (www.nooj4nlp.net), an instrument that allows one to construct largecoverage dictionaries and complex grammars in order to parse corpora. Hungarian version of NooJ makes automatic annotation of emotion terms possible. Using a general Hungarian dictionary part of speech, case, and number of each word was identified. This linguistic analysis was followed by a selection of emotion terms based on the NooJ dictionary of Hungarian emotion expressions. The automatic analysis was 
completed by a manual recheck of the emotion terms. At that point the concordance of explicit emotion terms, including 10 items altogether, was completed. ${ }^{4}$

In the next phase participants were asked to create a translation from the original Japanese text to Hungarian. The instruction was to aim for a literary translation that would convey the atmosphere of the text rather than a word-to-word translation. Through computational analysis and manual selection of these translations 10 concordances of emotion terms were produced. These wordlists varied in length from 8 to 14 items.

Concordances provided the possibility of 1) immediate quantitative comparison of explicit emotion terms, 2) analysis of corresponding terms and those not having an equivalent in the original text, and 3) the calculation and comparison of the level of linguistic abstraction in the 11 texts.

To test the results, the same excerpt from the English translation of the novel (Yoshimoto, 2001; translator: Backus, M.) was literally translated to Hungarian and analyzed the above explained way.

\section{Results}

Comparing the quantity of explicit emotion terms, an average surplus of $10 \%$ was found in participants' translations (109 phrases in the 10 texts).

The analysis of corresponding emotion terms has shown that explicit emotion expressions in the original text appeared in most cases also in Hungarian as emotion terms. However, in 12 cases explicit emotion phrases were missing from the different translations of the participants. Note that 7 out of 12 were missing from translations with at least 10 explicit terms. On the other hand, one part of the original text, that did not contain explicit reference to feelings, was translated using emotion terms by 6 participants.

\footnotetext{
${ }^{4}$ Explicit here refers to the distinction between words carrying emotional meaning by definition, such as 'anger', 'happy' and 'cry', and other linguistic markers of emotions, that are not necessarily lexicalized and are highly dependent on the context to function successfully as emotion markers. Markers that belong to the latter group are called implicit emotion expressions in the present paper. For a more detailed explanation see Bodor (2004).
} 


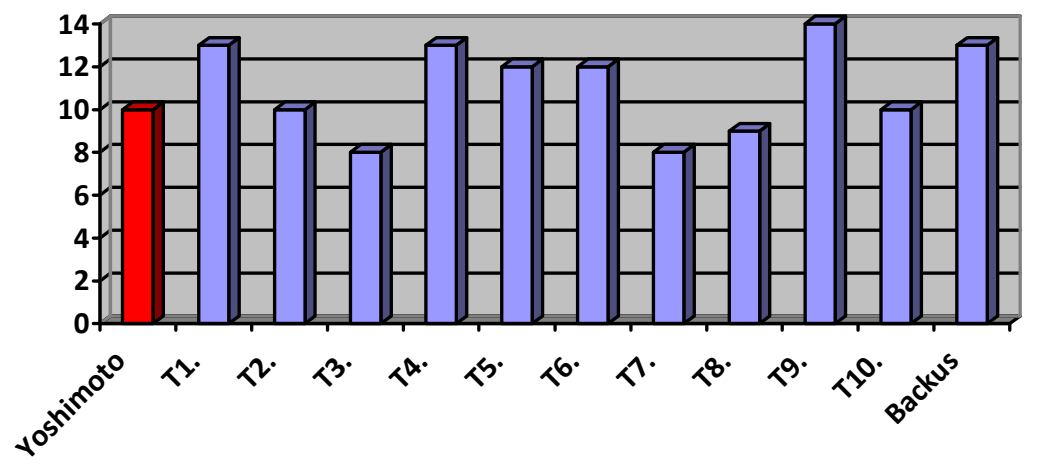

Figure 1: Number of explicit emotion expressions in the translations

Figure 1 shows the number of explicit emotion terms used in the 12 texts. Yoshimoto refers to the literal Hungarian translation of the original text, T1.-10. show the participants' translations of the original Japanese text to Hungarian, whereas Backus stands for the literal translation to Hungarian from the English edition of the novel.

A one-sample t-test using the level of linguistic abstraction in the original text $(3,3)$ and the mean level abstraction of the translations (3,507; Standard Deviation $=0,246)$ yielded a significant difference $(t(9)=2,653 ; p<0,05)$ in the linguistic abstraction of the Japanese text and the participants' Hungarian translations.

Results of the text translated from English correlate with those of the participants' translations. A surplus of $30 \%$ was identified in the text, with emotion terms appearing here too at the paragraph without explicit emotion terms in the original and lacking equivalent of one term of the original text. The t-test also revealed that the level of abstraction $(3,61)$ does not differ significantly from that of the Hungarian translations $(t(9)=-1,32 ; p>0,05$ n.s. $)$, though it does from the Japanese.

\section{Discussion}

The data about the quantity of explicit emotion terms in the texts seem to support the hypothesis about the correlation of emotion regulation and linguistic representation of emotions. Nevertheless we have to consider the questions of (1) how can we account for the surplus in the Hungarian and English translations and (2) what could explain the missing emotion terms in the same translations?

For the first question a twofold answer may be given, in accordance with the nature of linguistic emotion representation. Extra emotion terms appear mostly as adjuncts of expressions that are translated as an equivalent of emotion words used in 
the original text. These terms seem to have the function of strengthening the effect of the equivalent, as if one word would not suffice to create the same atmosphere in the reader. An example of this can be seen in (1) and (2), the emotion terms underlined:

(1) となりに人がいては淋しさが増すからいけない。(Yoshimoto, 1991, p. 25) Tonari ni hito ga ite wa sabishisa ga masu kara ikenai.

"If there is someone next to me, sadness increases, so I cannot [be close to anyone]"

(2) I was too $\underline{\text { sad }}$ to be able to sleep in the same bed with anyone; that would only make the sadness worse. (Backus' translation; Yoshimoto, 2001, p. 16)

The terms "sad" and "sadness" both belong to the category referred to in the present paper as explicit emotion expressions and their relation to an emotion term in the original text can be identified with ease. This is the case by the majority of the surplus. Still, there is a group of additional emotion words in the translation, which seem to lack a straight connection to any of the original expressions and appear in the translation of the same paragraph.

An explanation for this may be the use of implicit emotion expressions, a group of lexical, grammatical and possibly even structural linguistic markers that add an invariable emotional flavor to an utterance. As Nomura (2003, p. 37) proposes, "it is recommended, that emotion terms are not limited to the classical types of emotion- and wish expressions, but one should understand them as one type of expressions showing emotions, i. e., temporary movements and states of a person's mind, verbalized in a text." In other words, he refers to an extended range of linguistic devices as emotion terms, similar to what we call implicit emotion expressions here. Nomura, examining the introductory sentences of the same novel by Yoshimoto states, that not only phrases, like "tamaranaku suki da" ("I love it desperately") and "sabishiku hoshi ga hikaru" ("stars are shining lonely") belong to emotion expressions, but considering their role in maintaining the emotional atmosphere of the narration, even words such as "kagayaku" ("sparkle"), "ii" ("good") and "motarekakaru" ("lean against") should be counted among emotion expressions. The paragraph in question, describing the night view of the city, contains several words and phrases that can fall into the above explained category, such as "kasuka na akari ni ukabu shokubutsutachi" ("plants floating in the dim light"), "sotto ikizuite ita" ("breathing softly"), "tōmei na kūki ga kirakira kagayaite" ("the transparent air sparkling brilliantly") and "migoto ni utsutte ita" ("was reflected beautifully"). These may imply feelings in the readers and many translators would even find words for those impressions.

As for the function of such implicit emotion expressions, Nomura (2003, p. 38) calls the attention to their close relation to the underlying evaluation that frames the narrated episodes. As he states, "to the extent [such expressions] share the connectedness of this evaluation, in the text there is an inherent structuring effect of the emotion expressions." Emotions thus seem to play an important role in creating the unity of story-telling. Narratives consist of episodic scenes, which in turn may be defined by their emotional atmosphere. If so, implicit emotions are expected to appear 
in any language at those parts of the narration, where for some reason explicit representation of feelings cannot take place. This may be related to the culture-specific rules of emotion regulation on the one hand, but it is most probably a universal feature of language use at the same time, considering the possibility that any language is likely to be dependent on indirect expression of feelings to some extent.

The idea of implicit and explicit emotion terms constituting an emotional and evaluative frame for segments of narration may be helpful in explaining the missing emotion words as well. It is notable, that emotion words explicitly stated in the original were left out from the translations only when a series of such expressions were concentrated within a sentence or sentences following each other. This can be illustrated by (3), a clause in which the first one of the two expressions was changed to a non-explicit emotional term in 6 translations.

(3) お気に入りの台所に立てたうれしさで目がさえてくると $\cdots$

Okiniiri no daidokoro ni tateta ureshisa de me ga saete kuru to...

"As my eyes cleared with the happiness of standing in my beloved kitchen..."

An example of changing an emotional term into an evaluative one can be seen in (4), a sentence from the text of T5.

(4) Amint a számomra oly' eszzményi konyhában boldogan álltam, hirtelen... "As I was standing happily in the kitchen so ideal to me, suddenly..."

The fact, that more than half of the translators decided to change one of the two explicit emotion terms in that clause to an evaluative phrase that may implicitly carry emotions suggests, that emotions require a somewhat even expression on the explicit level. The other half of the terms not to be found in the translations have become invisible in a similar, emotionally concentrated context in the first monologue of the text. $^{5}$

Through including a literal Hungarian translation of the English version by Backus, a comparison of the Japanese, Hungarian and English results become possible. 13 explicit emotion terms are used in the English translation, what is on a parallel with many of the participants' works ( 13 emotions terms by T1 and T4, 14 by T9, 12 by T5 and T6). A considerable surplus in English is also comparable to the results of the studies on emotion regulation cited in the introductory section.

Finally, the question of linguistic abstraction is to be discussed. The significant difference in the level of abstraction between the original text and the Hungarian and English translations appears to provide evidence that a more concrete formulation of

\footnotetext{
${ }^{5}$ Obviously, there is a possibility of the translators' personality influencing word-choice, but in that case no research on the personality traits of the translators was conducted. Undoubtedly this is a limitation of the study. Still, the homogeneity of the participants in terms of language learning and translation experience suggested that their translations can reveal common features of Hungarian emotion expression tendencies.
} 
emotions characterizes cultures highly valuing interdependence. The minor difference of Hungarian and English might imply some closeness in the habits of emotion expression in Western cultures. This result about Japanese and Hungarian cultures is in line with the findings of Semin et al. (2002) examining Turkish, HindustaniSurinamese and Dutch participants.

It is important to emphasize that the little sample of the present study does not allow us to draw any extensive conclusion. The fact that our results correlate with those of previous studies on the regulation and linguistic representation of emotions reassures that Japanese culture can and has to be placed in its context in cultural, linguistic and psychological sense as well. It is especially an important task in the light of the diverse results on the phenomena of individualism-collectivism and emotions (Kashima et al., 1995; Matsumoto, 1999). Cultural and linguistic habits may differ from people to people, yet in our view it is mostly a question of the degree a culture represents the universal regularities.

\section{Conclusion}

The present paper was devoted to two aspects of emotion expression as they appear in the language and culture of Japan compared to Hungary. The quantitative analysis of translations implies that emotional display rules of the Japanese culture are reflected in linguistic emotion expression too, resulting in a reduced use of explicit emotion terms. At the same time, lower level linguistic abstraction was found in Japanese language, suggesting a possibility of a difference in the function of emotion expressions in social interactions.

The way implicit emotion expression operates is one of the topics waiting for further research. Also, the question of emotional associations may be closely related to that. Another field of interest in connection with emotions is their role in constituting the unity during narration.

\section{References}

Bigazzi, S. \& Nencini, A. (2008). How evaluations construct identities: the psycholinguistic model of evaluation. In O. Vincze \& S. Bigazzi (Eds.), Élmény, tötrénet - a történetek élménye (pp. 91-105). Budapest: Új Mandátum Könyvkiadó.

Bodor, P. (2004). Az érzelmi fejlődés diszkurzív megközelítése: az érzés (feel). In M. Győri (Ed.), Az emberi megismerés kibontakozása - Társas kognició, emlékezet, nyelv (pp. 1740). Budapest: Gondolat.

Doi, T. (1981). The anatomy of dependence. Tokyo: Kodansha International. 
Ekman, P. (1972). Universals and cultural differences in facial expresions of emotion. In. J. Cole, (Ed.), Nebraska symposium on motivation (pp. 207-283). Lincoln, NE: University of Nebraska Press. (idézi Oatley és Jenkins, 2001)

Kashima, Y., Yamaguchi, S., Kim, U., Choi, S., Gelfand, M., \& Yuki, M. (1995). Culture, Gender, and Self: A Perspective From Individualism-Collectivism Research. Journal of Personality and Social Psychology, 69, 925-937.

Kitayama, S., \& Mesquita, B., \& Karasawa, M. (2006). Cultural Affordances and Emotional Experience: Socially Engaging and Disengaging Emotions in Japan and the United States. Journal of Personality and Social Psychology, 91, 890-903.

Kiyomi, S. (2006). Kanjōhyōgen no nichiēhikaku. Surugadaidaigakuronsō, 32, 91-114.

Maass, A. (1999). Linguistic intergroup bias: Stereotype perpetuation through language. In M. P. Zanna, (Ed.), Advances in Experimental Social Psychology, (Vol. 31, pp. 79- 121). New York: Academic Press.

Maass, A., Karasawa, M., Politi, F. \& Suga, S. (2006). Do Verbs and Adjectives Play Different Roles in Different Cultures? A Cross-Linguistic Analysis of Person Representation. Journal of Personality and Social Psychology, 90, 734-750.

Maass, A., Salvi, D., Arcuri, L., \& Semin, G. R. (1989). Language use in intergroup contexts: The linguistic intergroup bias. Journal of Personality and Social Psychology, 57, 981-993.

Maeda, T. (1993). Nihongo no kanjō wo arawasu kotoba. Nihongogaku, 12, 4-13.

Markus, H. R., \& Kitayama, S. (1991). Culture and the Self: Implications for Cognition, Emotion, and Motivation. Psychological Review, 98, 224-253.

Matsumoto, D. (1999). Culture and Self: An empirical assessment of Markus and Kitayama's theory of independent and interdependent self-construals. Asian Journal of Social Psychology, 2, 289-310.

Matsumoto, D., Yoo, S. H., Nakagawa, S., ... 37 Members of the Multinational Study of Cultural Display Rules. (2008). Culture, Emotion Regulation, and Adjustment. Journal of Personality and Social Psychology, 94, 925-937.

Miyamoto, Y., \& Ma, X. (2011). Dampening or Savoring Positive Emotions: A Dialectical Cultural Script Guides Emotion Regulation. Emotion, 11, 1346-1357.

Morschbach, H., \& Tyler, W. J. (1986). A Japanese emotion: Amae. In R. Harré (Ed.), The social construction of emotions (pp. 289-307). Oxford: Blackwell.

Nomura, M. (2003). Gendaigo no tekusuto ni okeru kanjōhyōgen. Nihongogaku, 22, 36-44.

Ohso, M. (2001). Kanjō wo arawasu dōshi-keiyōshi ni kansuru ichikōsatsu. Gengobunkaronshū, 22, 21-30.

Romney, A. K., Moore, C. C., \& Rusch, C. (1997). Cultural universals: Measuring the semantic structure of emotion terms in English and Japanese. Anthropology, 94, 5489-5494.

Safdar, S., Friedlmeier, W., Matsumoto, D., Yoo, S. H., Kwantes, C. T., Kakai, H., \& Shigemasu, E. (2009). Variations of Emotional Display Rules Within and Across Cultures: A Comparison Between Canada, USA, and Japan. Canadian Journal of Behavioural Science, 41, 1-10.

Semin, G. R., \& Fiedler, K. (1988). The cognitive functions of linguistic categories in describing persons: Social cognition and language. Journal of Personality and Social Psychology, 54, 558-568.

Semin, G. R., \& Fiedler, K. (1989). Relocating attributional phenomena within a languagecognition interface: The case of actors' and observers' perspectives. European Journal of Social Psychology, 19, 491-508. 
Semin, G. R., \& Fiedler, K. (1991). The linguistic category model: Its bases, applications, and range. In W. Stroebe \& M. Hewstone, (Eds.), European Review of Social Psychology (Vol. 2, pp. 1-30). Chicester, UK: Wiley.

Semin, G. R., Görts, C. A., Nandram, S., \& Semin-Goosens A. (2002). Cultural perspectives on the linguistic representation of emotion and emotion events. Cognition and Emotion, 16 (1), 11-28.

Semin, G. R. (2004). The Self-in-Talk: Towards an Analysis of Interpersonal Language and its Use. In J. Jost, M. R. Banaji \& D. A. Prentice (Eds.), Perspectivism in Social Psychology: The Yin and Yang of Scientific Progress (pp. 143-159). Washington, DC: APA Press.

Tanabe, Y., \& Oka, T. (2001). Linguistic intergroup bias in Japan. Japanese Psychological Research, 43, 104-111.

Uchida, Y., Townsend, S. S. M., Markus, R. H., \& Bergsieker, H. B. (2009). Emotions as Within or Between People? Cultural Variation in Lay Theories of Emotion Expression and Inference. Personality and Social Psychology Bulletin, 35, 1427-1439.

Wierzbicka, A. (1996). Japanese Cultural Scripts: Cultureal Psychology and "Cultural Grammar". Ethos, 24, 527-555.

Yoshimoto, B. (1991). Kitchin. Tokyo: Fukutake Bunko.

Yoshimoto, B. (2001). Kitchen. New York: Faber and Faber Limited. 